\title{
Mayotte Island: another important green turtle nesting site in the southwest Indian Ocean
}

\author{
Jérôme Bourjea $^{1, *}$, Julie Frappier ${ }^{2}$, Mireille Quillard ${ }^{3}$, Stéphane Ciccione ${ }^{4}$, \\ David Roos ${ }^{5}$, George Hughes ${ }^{6}$, Henri Grizel ${ }^{1}$ \\ ${ }^{1}$ Institut Français de Recherche pour l'Exploitation de la Mer (Ifremer) de La Réunion, Rue Jean Bertho, BP 60, \\ 97822 Le Port Cedex, La Réunion, France \\ ${ }^{2}$ Institut Français de Recherche pour l'Exploitation de la Mer (Ifremer) de Nouvelle-Calédonie, Station de Koné, \\ BP 2059, 98846 Nouméa Cedex, Nouvelle-Calédonie, France \\ ${ }^{3}$ Conseil Général de Mayotte, Observatoire des Tortues Marines, Direction de l'Environnement et du Développement \\ Durable, BP 101, 97600 Mamoudzou, Mayotte, France \\ ${ }^{4}$ Kelonia, l'observation des tortues marines de La Réunion, BP 40, 97898 Saint Leu Cedex, La Réunion, France \\ ${ }^{5}$ Institut Français de Recherche pour l'Exploitation de la Mer (Ifremer), Avenue Jean Monnet, BP171, 34203 Sète, France \\ ${ }^{6} 11$ Swainson's Lane, Amber Valley, Howick 3290, South Africa
}

\begin{abstract}
Situated in the north of the Mozambique Channel, Mayotte is the easternmost island of the Comoros Archipelago. From 1998 to 2005, Grande Saziley beach was monitored daily for green turtle Chelonia mydas nesting activity. Track surveys were monitored daily on 5 other adjacent beaches. Although nesting occurs throughout the year, nesting seasonality begins at the end of the wet season and intensifies during the dry season to reach an average nesting peak in June. In order to estimate the number of females nesting in the Saziley site and population trends over the study period, incubation success and number of nests per female and per season were estimated at 0.77 $( \pm 0.05 \mathrm{SD})$ and $3.03( \pm 0.37)$ respectively. With an average of 1545 nesting turtles per year $( \pm 439)$, the change in nesting numbers over the study period was so small that the population can be regarded as stable, with an estimated annual mean growth rate of 0.912 , confirmation that this population is both stable and in good health. Added support for this argument is demonstrated by the fact that the annual carapace size distribution of nesting females is stable, meaning that the nesting green turtle population of Mayotte is not ageing or rejuvenating. After due consideration of data on other nesting sites in the southwest Indian Ocean, the data from Mayotte emphasizes the fact that the green turtle is not an endangered species in this region. Even if it is still illegally exploited and alterations occur in their different habitats, the green turtle populations of this region seem to have successfully survived all threats during the past century.
\end{abstract}

KEY WORDS: Chelonia mydas $\cdot$ Population assessment $\cdot$ Seasonality $\cdot$ Nesting trend

\section{INTRODUCTION}

The green turtle Chelonia mydas is found circumglobally in subtropical waters and is a highly migratory, long-lived species with delayed sexual maturity and high adult survival but low hatchling survival. The species has had a long history of human exploitation in all oceans, with some stocks now extinct, others in decline (Frazier 1980, Witzell 1994) and some stocks showing significant restoration following dedicated conservation effort (Balazs \& Chaloupka 2004). However, in many areas the green turtle is now regarded as an endangered species due to overexploitation of eggs and adults on nesting beaches, by catches in fisheries and alterations in both nesting and feeding habitats (World Conservation Union [IUCN] Red List, Seminoff 2004). The southwestern Indian Ocean (SWIO) remains an important nesting and feeding ground for 
green turtles (Hughes 1973, Frazier 1975 1985, Le Gall et al. 1985, Mortimer 1985, Le Gall 1988, LauretStepler et al. 2007) even if, over the past few centuries, overexploitation and habitat destruction have resulted in the decrease and local extinction of a few populations in this region (Frazier 1975, Rakotonirina \& Cooke 1994). Sea turtle activities in many of the islands in the region are well monitored, especially on Europa, Tromelin, Grande Glorieuses (Hughes 1974, Le Gall et al. 1985, Lauret-Stepler et al. 2007), Comoros archipelago and Mayotte (Frazier 1985), Iranja island (Bourjea et al. 2006) and Reunion Island (Ciccione \& Bourjea, 2006). This region of the world is of significant interest to managers and scientists not just because it harbours large stocks of sea turtles, especially green turtles, but also because molecular evidence suggests a split between the green turtle population from the northern Mozambique Channel, being most closely related to the Indo-Pacific genetic stock and the population from the southern Mozambique Channel most closely related to the Atlantic stock (Bourjea et al. 2007b).

The technique most commonly used to assess population size and trend is to count the number of clutches laid in a season (Schroeder \& Murphy 1999), but track counts can also be used as an index of female abundance and change at the nesting sites, assuming that the mean number of tracks per female per season remains relatively constant through time (Seminoff 2004). However, accurate population assessment is more difficult when a population nests on many beaches and all year long. In such cases, labour intensive surveys are required but unfortunately quite often impossible to organize. Three options for population assessments are available; either limiting the counts to a small part of the year, for instance peak nesting periods only, or selecting specific sites to act as index beaches, or both in combination. In the case of key index beaches the biological data and trends are extrapolated to the rest of the island.

Mark-recapture programmes are indispensable for understanding nesting behaviour typical within a region, and are useful for comparing species behaviour on a site by site, region by region or ocean by ocean basis. Mayotte is the easternmost island of the Comoros Archipelago. It is an exceptional rookery for nesting green turtles comprising numerous suitable nesting sites (Frazier 1985) spread along the entire island. Two species of sea turtle are known to nest on this island: hawksbill Eretmochelys imbricata and green turtle, the latter being the most abundant. In addition to global protection laws, the Directorate of Agriculture and Forestry (DAF) in association with the Department Organization of Mayotte (CDM) strengthened the protection of sea turtles in 1994. This was done by developing specific protection and conservation plans for the entire island, with special features for the 2 sites (Saziley and Moya) most frequented by green turtles.

The fundamental goal of our study was to assess green turtle nesting activity at the Saziley rookery and hence, to analyse changes in 2 population health indicators that remain fundamental for conservation measures: the number of nests and carapace length. We describe here the design and implementation of the survey regime which allowed us to estimate these nesting indices.

\section{MATERIALS AND METHODS}

Study site. Mayotte Island ( $\left.15^{\circ} 33^{\prime} \mathrm{S}, 54^{\circ} 31^{\prime} \mathrm{E}\right)$ is one of the islands of the Comoros archipelago, situated in the north of the Mozambique Channel, between Madagascar and Mozambique (Fig. 1). This $374 \mathrm{~km}^{2}$ island is an Overseas Département of France which, in 2005, had 170 beaches that were suitable for turtle nesting. Some of the beaches are accessible to residents who use the beaches for recreational or ecotourism purposes. Saziley, however, is a protected area where tourism is controlled and turtles are monitored by special staff from the Department of Mayotte. Saziley has 6 discrete beaches with $2239 \mathrm{~m}$ of sandy beach suitable for nesting. The largest beach is Grande Saziley; this site can be reached on foot requiring a $1 \mathrm{~h}$ walk or a 30 min journey in a motorized boat.

Data collection. Since 1 January 1998, 4 teams of 2 nature guards patrolled the beach of Grande Saziley beach every night of the year. For each nesting green turtle found, they (1) made biometric measurements (curved carapace length, CCL), (2) noted aborted digging attempts or successful nests and (3) tagged each turtle with a classic 'Monel' metal tag (1005-46 Monel tag $035 \mathrm{MO}$ ) or (4) recorded tag numbers of previously inserted tags.

Track surveys on nesting beaches are often used to assess nesting sea turtle populations (Schroeder \& Murphy 1999). These utilise the fact that each time a female sea turtle emerges from the water to attempt nesting, called 'nesting activity' (Godley et al. 2001), it creates a set of tracks on the sand, one ascending and the other one descending to the sea. By counting all the tracks on the beach, and dividing by 2 , it is possible to infer how much nesting activity occurred on a particular beach in any given period. Since 1 January 1998, the team has patrolled each of the 6 beaches at the Saziley site every morning and recorded the number of nesting turtle tracks on the assigned beach to determine nesting activity. Once recorded, the nature guard cancels the tracks to avoid double-counting the next day. 


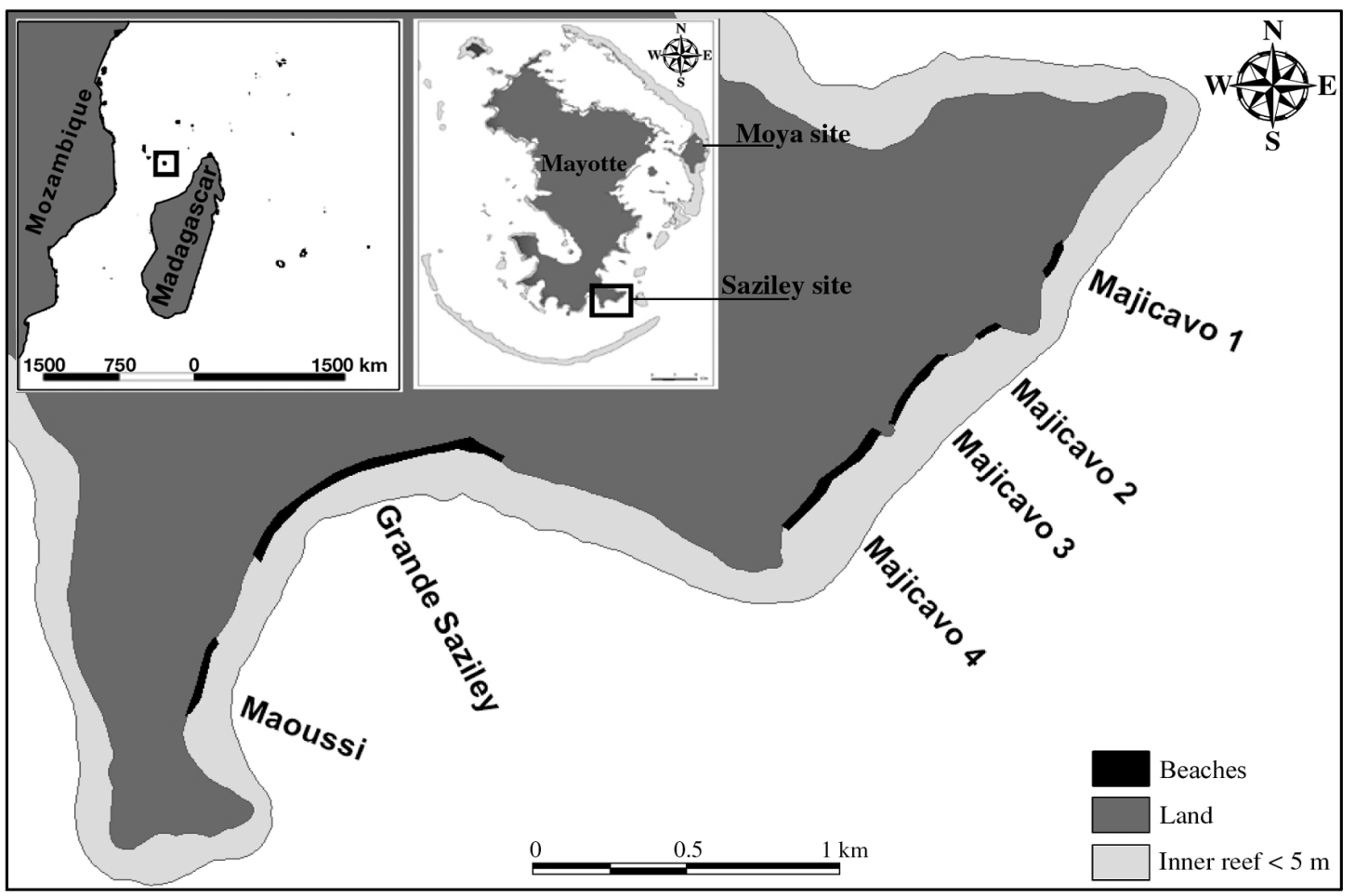

Fig. 1. Saziley site on Mayotte $\left(15^{\circ} 33^{\prime} \mathrm{S}, 54^{\circ} 31^{\prime} \mathrm{E}\right)$ illustrating green turtle nesting beaches. This site consists of 6 beaches (Maoussi, Grande Saziley and Majicavo 1, 2, 3 and 4). Only Grande Saziley is monitored every night for tagging, carapace measuring, track counting and nesting activity of female green turtles. The other 5 beaches are only monitored in the morning for tracks

Calculation of nesting indices. The calculation of the following nesting indices is based on the daily markrecapture monitoring (due to the large number of gaps and inadequate coverage, data from 1994 to 1997 were not used in the calculation of nesting indices).

Within season renesting interval: Green turtles often lay more than one clutch of eggs during a nesting season. We assessed nesting intervals using a compilation of all renesting intervals (in number of days) recorded at Grande Saziley.

Nesting success: Turtles do not lay eggs during every nesting emergence and can abort nesting efforts at a number of different stages of the nesting process, returning to the sea to re-emerge the next night or on some subsequent night. In this study, we calculated the nesting success $\hat{r}$ for Grande Saziley as the ratio between the number of activities observed $\left(\mathrm{NA}_{\mathrm{obs}}\right)$ and the number of nests observed $\left(\mathrm{NN}_{\mathrm{obs}}\right)$ in a nesting season:

$$
\hat{r}=\frac{\mathrm{NA}_{\text {obs }}}{\mathrm{NN}_{\mathrm{obs}}}
$$

Numbers of nestings per female: We calculated the mean number of nestings per female and per season $\hat{m}$ as the ratio between $\mathrm{NA}_{\text {obs }}$ and the total number of individuals identified by a Monel tag and observed on a site $\left(\mathrm{NI}_{\mathrm{obs}}\right)$ within the nesting period:

$$
\hat{m}=\frac{\mathrm{NA}_{\mathrm{obs}}}{\mathrm{NI}_{\mathrm{obs}}}
$$

Total number of nesting females. For the 6 nesting beaches surveyed over the period, we estimated the total number of tracks (TNT) with the monthly assessed data. The total number of nesting females (TNF) was then calculated using $\hat{r}$ and $\hat{m}$ as follows:

$$
\mathrm{TNF}=\frac{\mathrm{TNT} \times \hat{r}}{\hat{m}}
$$

Trend analysis. We compiled the nest abundance time series for the Saziley site (1 of the 2 major green turtle nesting sites of Mayotte) based on the nesting indices determined with tagging-recapture data. We then estimated the underlying time-specific trend in Mayotte nest abundance over the study period using a smoothing spline ANOVA model (Chaloupka et al. in press) implemented in R 2.2.0 (Ihaka \& Gentleman 1996). This non-parametric approach uses the data to determine the smooth trend with 95\% Bayesian confidence curves without assuming any specific functional form. We assumed that the fit was reasonably linear, so 
an estimate of the linear trend from a linear regression accounted for autocorrelation and weighted variance of the smooth estimate. The advantage of this approach is that it enables robust estimation of the mean growth rate. We used all the data in natural $\log$ form.

Lastly, we investigated the expected size distribution of female green turtles nesting each year on Grande Saziley beach using schematic box plot summaries, as long-term size distribution data are available for this site only.

Additional information. We estimated and graphed the average monthly minimum and maximum temperatures and the average monthly rainfall. We obtained historical meteorological data from the Météo France weather station based at Mayotte airport which provided us with data from 1 January 1998 to 1 January 2006.

\section{RESULTS}

\section{Monitoring, nesting indices and seasonality}

The nature guards have monitored the nesting turtle activity on 6 beaches of Saziley site (Fig. 1) daily since 1998. For Grande Saziley beach, the guards were active on $91 \%$ of the days in this period, counted 13415 tracks corresponding to 5167 nests, tagged and measured 3090 female green turtles and recorded 6025 recaptures (Table 1). For the 5 other beaches (Fig. 1), the guards surveyed $>85 \%$ of the total number of days in the period and counted 28993 tracks. Because the guards surveyed the beaches in the morning, they did not conduct tagging on these 5 beaches and they did not collect data on aborted digging attempts or successful nests.

Using all the data on tracks, we established the temporal distribution of the green turtle tracks for the 8 seasons from January 1998 to December 2005 (Fig. 2). The peak of nesting activity was during the austral winter, in June, with an average of 715 tracks counted over the 6 beaches in this month. It should be noted that $90 \%$ of the tracks occurred between 5 February and 28 October and $95 \%$ between 11 January and 15 December.

For the within-season renesting interval, we compiled a list of all the renesting intervals recorded at Grande Saziley during the 1998 to 2005 periods (Fig. 3). Three peaks were identified (Fig. 3). The first peak represented an interval of 0 to $7 \mathrm{~d}$ (average: $2 \mathrm{~d}$ ) and clearly comprises females that aborted their first nesting attempt and came back 1 to 7 d later $(n=1451)$. We noted that $25 \%$ of the female green turtles aborted

Table 1. Chelonia mydas. Summary of the monitoring (from 1998 to 2005) on Grande Saziley beach: number of taggings and recaptures, number of nests and tracks counted and the respective equivalent effort in day monitoring (monitoring effort was the same for both 'No. of nests' and 'No. of tracks'). TNT (total number of tracks) was estimated filling in the missing data by a $10 \mathrm{~d}$ extrapolation based on the sampling rate; $\hat{r}$ (nesting success) and $\hat{m}$ (number of nestings per female) were estimated with the tagging recapture data and the number of nests recorded per female. TNF (total number of females) was estimated with the calculated nesting indices

\begin{tabular}{|c|c|c|c|c|c|c|c|c|c|}
\hline Year & Tagging & Recapture & No. of nests & $\begin{array}{l}\text { No. of } \\
\text { tracks }\end{array}$ & $\begin{array}{l}\text { Effort } \\
\text { (d) }\end{array}$ & TNT & $\hat{r}$ & $\hat{m}$ & TNF \\
\hline 1998 & 347 & 939 & 779 & 1837 & 338 & 1956 & 0.82 & 3.66 & 438 \\
\hline 1999 & 398 & 862 & 787 & 1781 & 320 & 1957 & 0.82 & 3.06 & 524 \\
\hline 2000 & 265 & 576 & 444 & 1205 & 343 & 1280 & 072 & 3.48 & 263 \\
\hline 2001 & 617 & 932 & 854 & 2335 & 314 & 2723 & 0.76 & 2.65 & 779 \\
\hline 2002 & 286 & 481 & 334 & 1230 & 292 & 1592 & 0.69 & 2.69 & 408 \\
\hline 2003 & 473 & 820 & 750 & 1788 & 338 & 1964 & 0.78 & 2.88 & 536 \\
\hline 2004 & 305 & 647 & 587 & 1487 & 353 & 1527 & 0.83 & 3.04 & 416 \\
\hline 2005 & 399 & 768 & 632 & 1752 & 358 & 1788 & 0.77 & 2.73 & 502 \\
\hline Total & 3090 & 6025 & 5167 & 13415 & & & & & \\
\hline Average & & & & & & & 0.77 & 3.03 & 483 \\
\hline SD & & & & & & & 0.05 & 0.37 & 148 \\
\hline
\end{tabular}




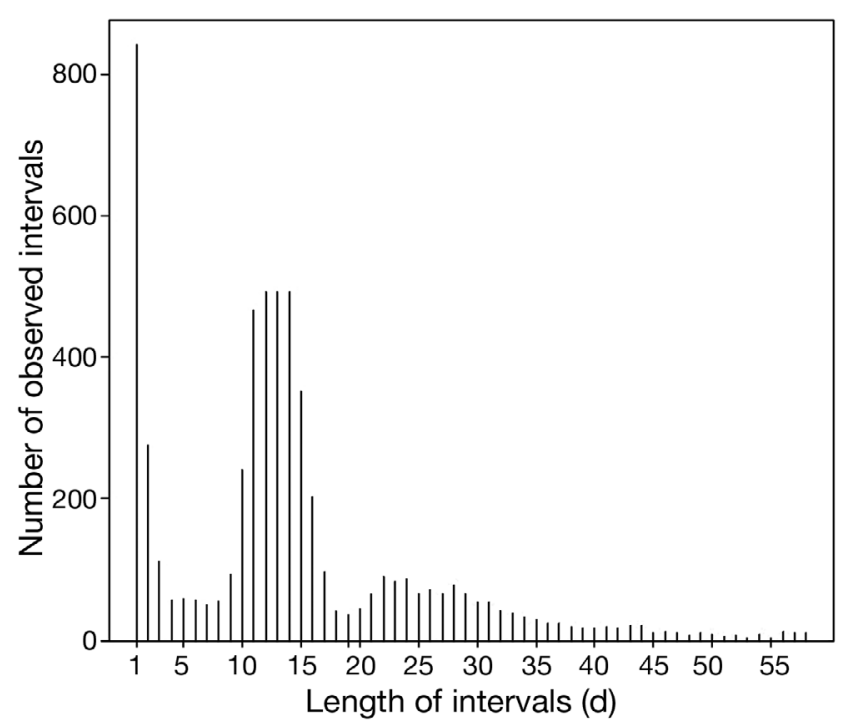

Fig. 3. Chelonia mydas. Time intervals separating consecutive nesting attempts by Grande Saziley green turtles based on tag recoveries between 1 January 1998 and 31 December 2005

their first nest and came back the following day. The second peak centred on 12 to $14 \mathrm{~d}(\mathrm{n}=3105)$, meaning that turtles nest again after an interval of 12 to $14 \mathrm{~d}$. The third and least frequently observed peak centred on 25 to $28 \mathrm{~d}(\mathrm{n}=1009)$ and represents the third nest of the same turtle during a nesting period. Even if in some cases, renesting occurs more that $150 \mathrm{~d}$ after the first emergence, no other category can be clearly identified.

Over the study period, we recorded the nesting activities of 90 turtles over several separate seasons. The interval between 2 nesting seasons was estimated at $3 \mathrm{yr}(\mathrm{SD}=1)$. We also estimated a nesting success $(\hat{r})$ of $0.77( \pm 0.05 \mathrm{SD})$ and a number of nests per female per season $(\hat{m})$ of $3.03( \pm 0.37$; Table 1$)$. Based on the estimation of $\hat{r}$ and $\hat{m}$, we estimated that an annual average of 483 females $( \pm 148$, Table 1$)$ nested at Grande Saziley, an 800 m long black sandy beach, suggesting an annual average of 600 turtles per kilometre of beach.

\section{Long-term nesting trend and trend in size of nesting females}

The distribution of nest abundance over the study period (Fig. 4) shows the annual periodicity of the nesting period identified in Fig. 2. Variations in the estimated nesting peak appear year to year, with the highest peak in 2005 ( $n=342$ nests in May). In order to establish the trend over this 8 yr period, we implemented a smoothing spline ANOVA model (Cha-

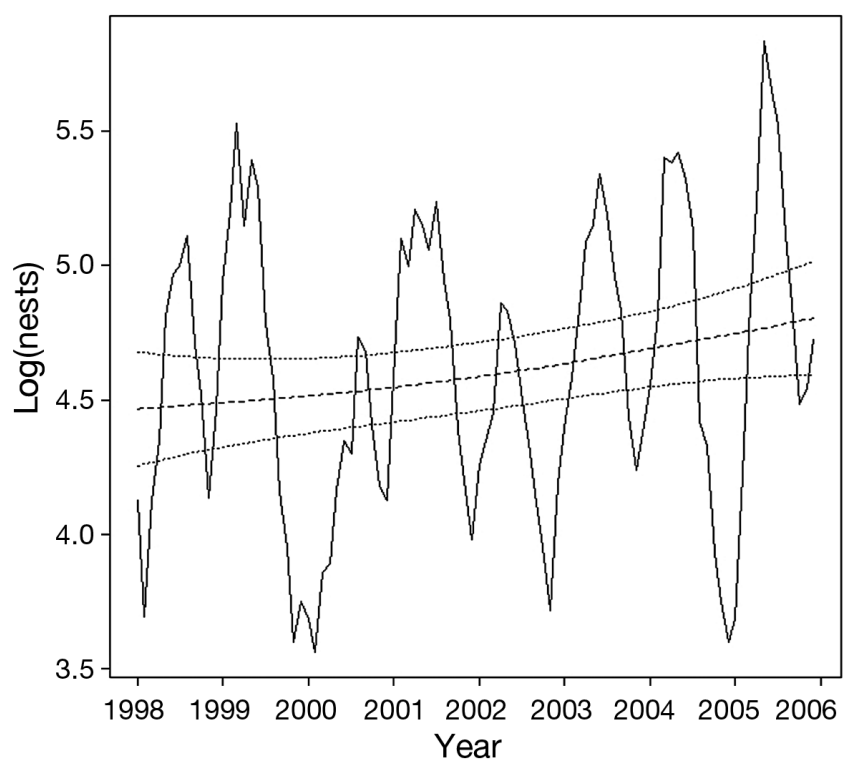

Fig. 4. Chelonia mydas. Long-term trend of green turtle nesting abundance for Grande Saziley beach (Mayotte). Solid line: recorded green turtle nesting from 1998 to 2005; central dotted line: estimated underlying trend in nest abundance for the same period; lower and upper dotted lines: 95\% Bayesian confidence curves

loupka et al. 2007). The long-term trend in nest abundance was assessed from 1998 to 2005 and appeared to increase over the period. This increase is verified by the estimated mean growth rate $\delta=0.912$.

Box plot summaries of the annual size distribution of green turtles nesting over the 8 yr sampling period on Grande Saziley beach are shown in Fig. 5. The overall median for the $8 \mathrm{yr}$ sampling period is shown by the solid horizontal bar, which is $108 \mathrm{~cm}$ curved carapace length (CCL). The size distribution for each annual sample fluctuates around the overall median without any obvious long-term trend.

\section{DISCUSSION}

\section{Nesting indices}

The tagging-recapture effort over Saziley beach was intense over the study period, with $>91 \%$ of the days monitored (Tables $1 \& 2$ ); this allowed us to estimate what is generally believed to reflect the biological reality of the different nesting indices.

Green turtles lay several times over a reproductive season, but the average time between consecutive nesting emergences varies from population to population, with a mean global renesting period of $12 \mathrm{~d}$ (range: 10 to $17 \mathrm{~d}$; Miller 1997). Our study based on more than 13400 nesting records shows that between- 


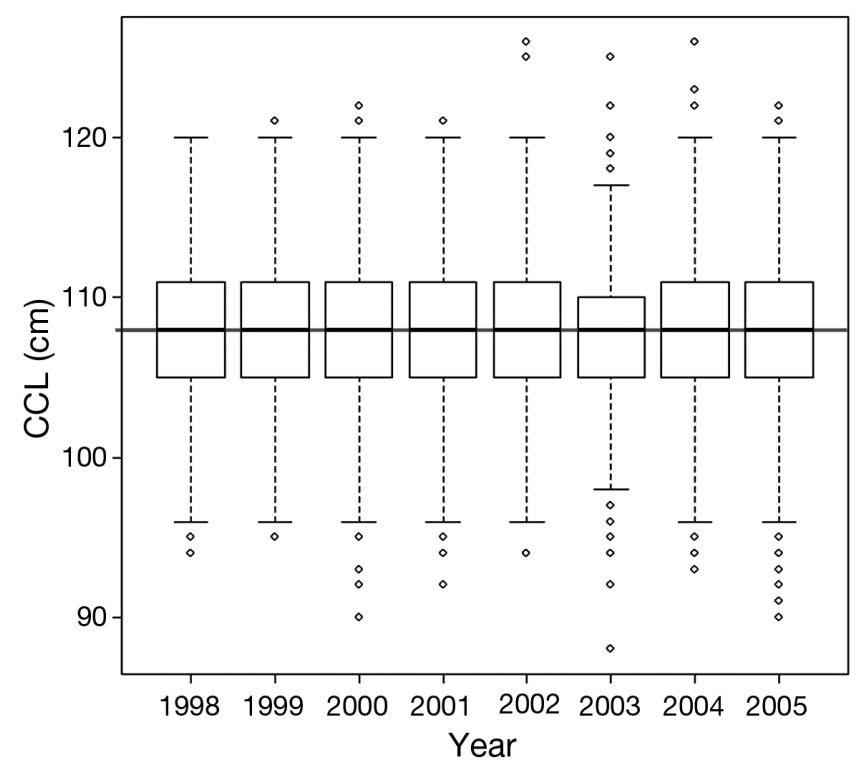

Fig. 5. Chelonia mydas. Box and whisker plot summary of the annual CCL (curved carapace length) distribution of green turtles nesting over the 8 yr sampling period on Grande Saziley beach. Thick horizontal line in each box: 50th percentile (median) of carapace size for each annual sample; upper and lower boundaries of each box: 75th and 25th percentiles; top and bottom of the whiskers: 90th and 10th percentiles; points above the 90th percentile: extreme outliers. Horizontal line: overall median (108 $\mathrm{cm} \mathrm{CCL}$ ) for the $8 \mathrm{yr}$ sampling period

nesting periodicity in Mayotte falls within the known range for green turtles. Records indicate a period of 12 to $14 \mathrm{~d}$ for the second nest. Lesser peaks (Fig. 3) roughly correspond to multiples of 12 to $14 \mathrm{~d}$. Equivalent data were found by Mortimer \& Carr (1987) in Ascension Island, and in the Indian Ocean (Le Gall 1988). Furthermore, we believe that the first peak, around $2 \mathrm{~d}$ (Fig. 3), indeed all turtles that came back before $8 \mathrm{~d}$, are those returning after an aborted attempt to nest. This agrees with other studies (Balazs 1980, Le Gall 1988). Green turtles are also known to lay as many as 11 clutches in one season (Hendrickson 1958). In our study, although one female emerged 15 times over the nesting season, laying 10 nests in 2001, the average green turtle nests 3 times $(\hat{m}=3.03 \pm$ $0.37 \mathrm{SD}$ ) in a season. Equivalent results were found in Ascension Island ( $\hat{m}=3.0$; Mortimer \& Carr 1987), in Tortuguero, Costa Rica ( $\hat{m}=2.8$; Carr et al. 1978) and in the Indian Ocean on Tromelin and Europa islands ( $\hat{m}=3.5$ and $\hat{m}=2.8$, respectively; Le Gall 1988).

Nesting success on Saziley beach $(\hat{r}=0.77 \pm 0.05 \mathrm{SD})$ appears higher than some other nesting sites $(\hat{r}=0.66 \pm$ 0.0095 at Europa, Le Gall 1988; $\hat{r}=0.56 \pm 0.004$ at Tromelin, Le Gall 1988; $\hat{r}=0.33 \pm 0.08$ at Ascension Island, Godley et al. 2001). Limpus et al. (2003) showed a very high variability in the nesting success on Raine Island (Australia) and proposed that the nesting success is influenced by various parameters such as nesting density on the beach, and rain. These data illustrate the variability that can occur in nesting success for turtles attempting to nest in coralline sand.

This high variability does not occur at the Saziley nesting site, where nesting success remained the same over the years studied (Table 1). It should be noted that the beaches at this site are composed of a mixture of coralline (white) and volcanic (black) sands, ranging from $>90 \%$ of coralline sand at Majicavo 1 to $>90 \%$ volcanic sand at Grande Saziley beach (Fig. 1).

We assessed remigration intervals using the data collected on 90 turtles recaptured during this 8 yr study on Grande Saziley beach, Europa and determined that the most frequent remigration interval for the green turtle is $3 \mathrm{yr}_{\text {; }}$ this agrees with the most commonly observed multi-annual renesting interval for this species (Le Gall et al. 1985, Miller 1997, Troëng \& Chaloupka 2007). The multi-annual recapture rate on Grande Saziley, a beach flanked by several other

Table 2. Chelonia mydas. Summary of the monitoring (1994 to 2005) on 5 beaches of the Saziley site: number of tracks counted and the equivalent effort in day monitoring. TNT (total number of tracks) was estimated filling in the missing data by a $10 \mathrm{~d}$ extrapolation based on the sampling rate. TNF (total number of females) was estimated with the calculated nesting indices on Grande Saziley

\begin{tabular}{|c|c|c|c|c|c|c|c|c|c|c|c|c|}
\hline \multirow[t]{2}{*}{ Year } & \multicolumn{2}{|c|}{ Maoussi } & \multicolumn{2}{|c|}{ Majicavo 1} & \multicolumn{2}{|c|}{ Majicavo 2} & \multicolumn{2}{|c|}{ Majicavo 3} & \multicolumn{2}{|c|}{ Majicavo 4} & \multirow[t]{2}{*}{ TNT } & \multirow[t]{2}{*}{ TNF } \\
\hline & $\begin{array}{l}\text { No. of } \\
\text { tracks }\end{array}$ & $\begin{array}{l}\text { Effort } \\
\text { (d) }\end{array}$ & $\begin{array}{l}\text { No. of } \\
\text { tracks }\end{array}$ & $\begin{array}{l}\text { Effort } \\
\text { (d) }\end{array}$ & $\begin{array}{l}\text { No. of } \\
\text { tracks }\end{array}$ & $\begin{array}{l}\text { Effort } \\
\text { (d) }\end{array}$ & $\begin{array}{l}\text { No. of } \\
\text { tracks }\end{array}$ & $\begin{array}{l}\text { Effort } \\
\text { (d) }\end{array}$ & $\begin{array}{l}\text { No. of } \\
\text { tracks }\end{array}$ & $\begin{array}{l}\text { Effort } \\
\text { (d) }\end{array}$ & & \\
\hline 1998 & 596 & 290 & 143 & 238 & 517 & 295 & 821 & 295 & 1085 & 296 & 3699 & 945 \\
\hline 1999 & 668 & 318 & 155 & 320 & 401 & 321 & 713 & 321 & 881 & 321 & 3095 & 791 \\
\hline 2000 & 787 & 334 & 139 & 333 & 439 & 334 & 606 & 334 & 814 & 334 & 3027 & 774 \\
\hline 2001 & 1048 & 302 & 477 & 306 & 873 & 307 & 1215 & 306 & 1670 & 305 & 6403 & 1636 \\
\hline 2002 & 539 & 280 & 148 & 280 & 394 & 280 & 688 & 279 & 766 & 279 & 3346 & 855 \\
\hline 2003 & 950 & 312 & 455 & 316 & 783 & 316 & 1008 & 316 & 1275 & 317 & 5077 & 1297 \\
\hline 2004 & 854 & 331 & 242 & 329 & 470 & 333 & 781 & 332 & 1021 & 333 & 3634 & 929 \\
\hline 2005 & 896 & 311 & 275 & 265 & 767 & 324 & 1123 & 324 & 1510 & 324 & 4976 & 1272 \\
\hline
\end{tabular}


beaches, is low $(2.4 \%$ of the total number of tagged turtles), and these results are similar to those obtained by studies on many other green turtle populations. Le Gall et al. (1985) found a similar rate (3.82\%) for a beach on Europa Island in the south of the Mozambique Channel. However, Le Gall et al. (1985) also found a recapture rate of $2.17 \%$ for Tromelin Island, which, in contrast to Europa and Mayotte, has only a single beach, meaning that green turtle fidelity to a specific beach is not necessarily dependent on the presence of other beaches adjacent to it.

\section{Total nesting females on 6 beaches at Mayotte}

Based on the estimated nesting indices $\hat{r}$ and $\hat{m}$ calculated on Saziley beach and on the daily track monitoring since 1998 on 6 beaches of Mayotte, it was possible to estimate the annual number of green turtle females nesting on these 6 beaches: 1545 ( \pm 439 SD) nesting turtles (calculation based on Tables $1 \& 2$ ). Even if the nesting success on Saziley beach $(\hat{r}=0.77 \pm$ $0.05)$ and the number of nests per female $\left(\hat{m}_{1}=3.03 \pm\right.$ 0.37 ) do not vary very much from year to year on Grande Saziley, the estimation of the number of green turtle females nesting on these 6 beaches should be considered as an order of magnitude, not as the field reality. We need to consider that there are numerous parameters that were not taken into account for the calculation, such as site fidelity, tag losses, variability in the remigration intervals and weak synchrony in the remigration behaviour.

The Saziley site is one of the two main nesting sites of Mayotte. The other is the site of Moya (Fig. 1), where the estimated number of nesting turtles seems to be similar to that on Grande Saziley beach, meaning that $>2000$ turtles nest on these 2 sites. Even if the other beaches around Mayotte do not have the same level of nesting green turtles, with a total of 170 beaches suitable for nesting sea turtles (BDTopo Mayotte), Mayotte Island represents another very valuable colony of green turtles in the SWIO. In this region, it has been estimated that Europa Island hosts a colony of 3000 to 10000 females $\mathrm{yr}^{-1}$, Tromelin Island hosts 1000 to 3000 (Le Gall et al. 1986), Moheli in the Islamic Republic of the Comores 1000 to 3000 (G. Hughes pers. comm.), Aldabra 6000 to 8000 (Mortimer 1985) and a portion of Grande Glorieuse Island hosts $1480 \pm 480$ (Lauret-Stepler et al. 2007). Considering the other nesting sites in the Seychelles archipelago (Cosmoledo, Amirantes), Mozambique (Bazaruto, Primeiras and Segundas), all the east coast of Africa and Madagascar and the St Brandon Shoals of Mauritius, it is clear that the SWIO is an extremely important region for nesting green turtles.

\section{Temporal distribution of nesting effort}

Although nesting occurs throughout the year, nesting seasonality on Mayotte begins at the end of the wet season, intensifies during the dry season, with an average nesting peak in June and ends at the beginning of the new wet season (Figs. 2 \& 6). Nesting seasonality patterns on Mayotte are therefore similar to those of the majority of green turtle colonies studied worldwide; many colonies globally have nesting throughout the year with a distinct nesting peak at a specific season (see for example Bjorndal et al. 1999, Chaloupka 2001, Godley et al. 2002).

Within the SWIO, different seasonality patterns were recorded, with nesting peaks occurring during the dry season in the north of the Mozambique Channel (Mayotte; Grande Glorieuse island, Lauret-Stepler et al. 2007; Iranja Island, Bourjea et al. 2006) and during the wet season for the south of the Mozambique Channel (Europa Island; Lauret-Stepler et al. 2007). The SWIO green turtle seasonality pattern seems to be correlated with genetic structuring in the region: there is compelling genetic evidence that green turtles nesting in the rookeries of the south Mozambique Channel (SMC) and those nesting in the north Mozambique Channel (NMC) belong to separate genetic stocks (Bourjea et al. 2007b).

However, the Tromelin rookery off the east coast of Madagascar and part of the NMC stock show a seasonality pattern where peak nesting occurs during the wet season, as for rookeries from SMC stock, meaning that other external factors could be involved (Lauret-

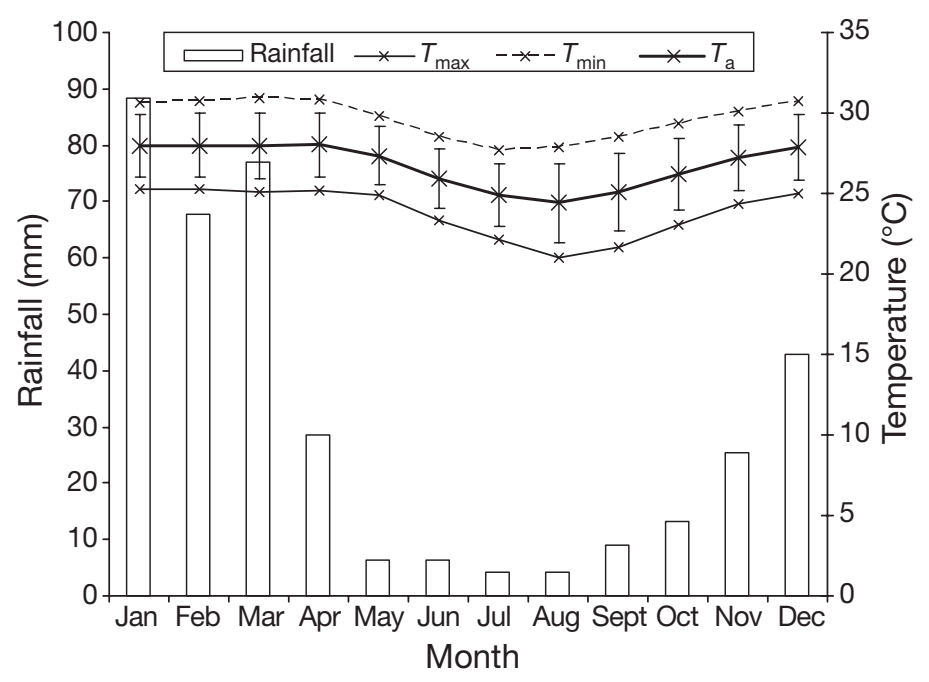

Fig. 6. Monthly mean of maximum $\left(T_{\max }\right)$, minimum $\left(T_{\min }\right)$ and average air temperature $\left(T_{\mathrm{a}}\right)$ and rainfall in Mayotte (1 January 1998 and 31 December 2005). SE is given for $T_{\mathrm{a}}$. Data were obtained from Météo France for the east coast of Mayotte 
Stepler et al. 2007). Based on data on Australian green turtle rookeries, Limpus et al. (2003) proposed that this variability in timing of the nesting season probably results from the interaction of a number of factors which are thought to include the genetic origin of the population, but also the temperature regime of the rookery and the climate of the feeding grounds providing turtles to the rookery. A large regional analysis of nesting seasons based on sea surface temperature (SST), air temperature, and rainfall variation is clearly needed; these data should, however, be procured not only from island but also from mainland rookeries (i.e. Madagasacar, East African coast).

\section{Long-term nesting trend}

Changes in nesting numbers over the study period are low, with an estimate mean growth rate of 0.912 (Fig. 4). Sea turtles have been protected in Mayotte since 1994, and the time series analysis confirms that protection of nesting sites does have a positive impact on nesting populations, as has been observed in other studies (Chaloupka \& Limpus 2001, Balazs \& Chaloupka 2004, Troëng \& Rankin 2005). Where committed conservation measures have been introduced, the increase in nesting numbers has been dramatic, for instance on Heron Island, Australia (Chaloupka \& Limpus 2001), Hawaii, USA (Balazs \& Chaloupka 2004), or Tortuguero, Costa Rica (Troëng \& Rankin 2005). This suggests that the population of green turtles in Mayotte before the implementation of conservation measures was not over-exploited. Added support for this argument is that the overall median for each annual sample of CCL was stable over the study period (Fig. 5), meaning that the nesting green turtle population of Mayotte is not ageing or rejuvenating: a sign that this population is both stable and in good health. This argument is only valid if we assume that there is no significant change in the size of first maturity over the study period.

However, as shown in other studies (Le Gall 1988, Hays et al. 1999, Solow et al. 2002), the high interannual variability in the number of nests can render the interpretation of trends for the different sites difficult, especially over short-term study periods. Variability in the remigration intervals and weak synchrony in the remigration behaviour of the nesting individuals can account for the inter-annual variability in the number of individuals seen in a colony (Solow et al. 2002). Environmental factors such as cyclones and El Niño Southern Oscillation associated with warmer sea surface temperatures were found to influence the number of individuals migrating to their nesting sites, causing this high inter-annual variability (Limpus \& Nicholls 1988, Solow et al. 2002, Ross 2005).

\section{Status of the green turtle in the SWIO}

The data collected on Mayotte (Roos et al. 2005, Taquet et al. 2006, present study) showed astonishing abundance of foraging and nesting green turtles, and since monitoring started, data on nesting green turtles from other nesting sites in the SWIO have shown stability or significant increases; Mortimer (1985), LauretStepler et al. (2007) and the present study suggest that this has been achieved through long-term conservation measures. Thus, it appears that the green turtle is not an endangered species in this region.

This means that following the near collapse of large green turtle rookeries in the early twentieth century (e.g. Aldabra and Europa), the now large green turtle population of the SWIO seems capable of supporting the present level of exploitation.

However, sea turtles are still illegally exploited and by-caught in the SWIO, mainly in Madagascar (Rakotonirina \& Cooke 1994), the Comoros archipelago and the east African coast. The question is: What will happen if exploitation increases or there are dramatic alterations in both nesting and feeding habitats? In the case of Mayotte, with the large increase of tourism on this island (from 21000 tourists in 1999 to 39000 in 2005; data from Institut National de la Statistique et des Etudes Economiques-INSEE, 2007) and demographic growth (130 000 inhabitants in 1997 to 185000 in 2006; data from INSEE), negative impacts on the coastal environment, and thus on sea turtle nesting and foraging habitat, will inevitably occur. Conservation measures seem to be the only way to regulate those human activities on the coast that could influence the resident and nesting populations of sea turtles. Furthermore, in addition to ensuring the preservation of sea turtles, if these conservation measures are well implemented they can have a positive economic impact on this small island with limited economic resources using this flagship species for the development of ecotourism.

Another point of concern is that, even if the recent results on population monitoring in the main nesting sites of the SWIO are positive, it remains important to increase the monitoring in other smaller nesting sites such as Madagascar (Bourjea et al. 2006) or along the east coast of Africa. This is essential because small rookeries play an important role in the genetic diversity of this species in a zone that has populations from the Atlantic and from the Indo-Pacific Oceans (Bourjea et al. 2007b). More studies need to be carried out on foraging grounds in order to determine where conservation measures are necessary. Turtles nesting on Mayotte seem to feed on the east African coast, mainly Tanzania and Kenya (J. Bourjea pers. comm.) where sea turtles are still threatened by harvesting and 
by-catch in small-scale and commercial fisheries (Bourjea et al. 2007a).

In conclusion, we believe that the results of this study on Mayotte confirm the existence of yet another stable to increasing population of green turtles protected in the SWIO which, added to those studies on other formally protected rookeries with stable or growing populations of green turtles nearby, further confirm our conviction that the region represents one of the world's most valuable green turtle stocks. The data collected through careful monitoring and accurate assessment should be of great value when the IUCN next reviews the global status of this valuable species.

Acknowledgments. The authors are most grateful for the financial support of this long-term survey and conservation programmes kindly provided by the Collectivité Départementale de Mayotte and the Direction de l'Agriculture et de la Forêt de Mayotte. We especially thank all the nature guards of the Cellule de Gestion des Terrains du Conservatoire du Littoral (CGTCL) who are in the field every day monitoring nesting sea turtles and doing an indispensable job. We are also grateful to D. Chanfi, M. Ali and R. Roland for their important contribution in the protection of sea turtles in Mayotte. We also acknowledge field support from La Brigade Nature of Mayotte. We thank the University of Sciences of Besançon, and especially Professor J. Y. Dauxois for his help with statistical analyses. Lastly, we thank R. Nel and $\mathrm{K}$. Ballorain for their helpful comments on the manuscript and we are extremely grateful for the comments by all three reviewers.

\section{LITERATURE CITED}

Balazs GH (1980) Synopsis of biological data on the green turtle in the Hawaiian Islands. NOAA Tech Memo NMFSSWFC-7

Balazs GH, Chaloupka M (2004) Thirty-year recovery trend in the once depleted Hawaiian green sea turtle stock. Biol Conserv 117:491-498

Bjorndal KA, Wetherall JA, Bolten AB, Mortimer JA (1999) Twenty-six years of green turtle nesting at Tortuguero, Costa Rica: an encouraging trend. Conserv Biol 13:126-134

Bourjea J, Ciccione S, Rantsimbazafy R (2006) Marine turtle survey in Nosy Iranja Kely, North-Western Madagascar. West Indian Ocean J Mar Sci 5:209-212

Bourjea J, Nel R, Jidawi N, Koonjul MS, Biancci G (2007a) Prospectus of a FAO workshop on assessing the relative importance of sea turtle mortality due to fisheries in the south-west Indian Ocean. In: Kiszka J, Muir C (eds) Incidental catch of non-targeted species in the western Indian Ocean: problems and mitigation measures. Workshop proceeding. 13-15th November 2006, Mayotte, France, p $35-44$

Bourjea J, Lapègue S, Gagnevin L, Broderick D and others (2007b) Phylogeography of the green turtle, Chelonia mydas in the Southwest Indian Ocean. Mol Ecol 16:175-186

Carr A, Carr MH, Meylan AB (1978) The ecology and migrations of sea turtles, 7 . The West Caribbean green turtle colony. Bull Am Mus Nat Hist 162:1-46
Chaloupka M (2001) Historical trends, seasonality and spatial synchrony in green sea turtle egg production. Biol Conserv 101:263-279

Chaloupka M, Limpus CJ (2001) Trends in the abundance of sea turtles resident in southern Great Barrier Reef waters. Biol Conserv 102:235-249

Chaloupka M, Bjorndal K, Balazs G, Bolten A and others (in press) Encouraging outlook for recovery of a onceseverely-exploited marine megaherbivore and restoration of its ecological function. Global Ecol Biogeogr

Ciccione S, Bourjea J (2006) Nesting of green turtles in Saint Leu, Réunion Island. Mar Turtle Newsl 112:1-3

Frazier J (1975) Marine turtles of the Western Indian Ocean. Oryx 13:164-175

Frazier J (1980) Exploitation of marines turtles in the Indian Ocean. Hum Ecol 8:329-370

Frazier J (1985) Marine turtles in the Comoro Archipelago. North-Holland Publishing Company, Amsterdam

Godley BJ, Broderick AC, Hays GC (2001) Nesting of green turtles (Chelonia mydas) at Ascension Island, South Atlantic. Biol Conserv 97:151-158

Godley BJ, Broderick AC, Frauenstein R, Glen F, Hays GC (2002) Reproductive seasonality and sexual dimorphism in green turtles. Mar Ecol Prog Ser 226:125-133

Hays GC, Godley BJ, Broderick AC (1999) Long-term thermal conditions on the nesting beaches of green turtles on Ascension Island. Mar Ecol Prog Ser 185: 297-299

Hendrickson JR (1958) The green sea turtle, Chelonian mydas (Linn.) in Malaya and Sarawak. Proc Zool Soc Lond 130:455-535

Hughes GR (1973) The sea turtles of south east Africa. Doctoral thesis. University of Natal, Durban

Hughes GR (1974) The sea turtles of south east Africa II. Oceanogr Res Inst Rep 36:1-96

Ihaka R, Gentleman R (1996) R: a language for data analysis and graphics. J Comput Graph Statist 5:299-314

Institut National de la Statistique et des Etudes Economiques-INSEE (2007) Le tableau economique de Mayotte, edition 2006-2007. INSEE, Paris

Lauret-Stepler M, Bourjea J, Roos D, Pelletier D, Ryan P, Ciccione S, Grizel H (2007) Reproductive seasonality and trend of Chelonia mydas in the SW Indian Ocean: a $20 \mathrm{yr}$ study based on track counts. Endang Species Res 3:217-227

Le Gall JY (1988) Biologie et évaluation des populations de tortues vertes Chelonia mydas des atolls Tromelin et Europa (Océan Indien S.O.). Mésogée 48:33-42

Le Gall JY, Lebeau A, Kopp J (1985) Estimation of green turtle Chelonia mydas hatchling on breeding places of Europa and Tromelin (Indian Ocean). Océanogr Trop 20:117-133

Le Gall JY, Bosc P, Château D, Taquet M (1986) Estimation du nombre de tortues vertes femelles adultes Chelonia mydas par saison de ponte a Tromelin et Europa (Océan Indien) (1973-1985). Océanogr Trop 21:3-22

Limpus CJ, Nicholls N (1988) The southern oscillation regulates the annual numbers of green turtles (Chelonia mydas) breeding around northern Australia. Aust Wildl Res 15:157-161

Limpus CJ, Miller JD, Parmenter CJ, Limpus DJ (2003) The green turtle, Chelonia mydas population of Raine Island and the northern Great Barrier Reef: 1843-2001. Mem Queensl Mus 49:349-440

Miller DM (1997) Reproduction in sea turtles. In: Lutz PL, Musick JA (eds) The biology of sea turtles. CRC Press, Boca Raton, FL, p $51-81$ 
Mortimer JA (1985) Recovery of green turtles on Aldabra. Oryx 19:146-150

Mortimer JA, Carr A (1987) Reproduction and migration of the Ascension Island green turtle (Chelonia mydas). Copeia 1987:103-113

Rakotonirina B, Cooke A (1994) Sea turtles of Madagascar their status, exploitation and conservation. Oryx 28:51-61

Roos D, Pelletier D, Ciccione S, Taquet M, Hughes G (2005) Aerial and snorkelling census techniques for estimating green turtle abundance on foraging areas: a pilot study in Mayotte Island (Indian Ocean). Aquat Living Resour 18:193-198

Ross JP (2005) Hurricane effects on nesting Caretta caretta. Mar Turtle Newsl 108:13-14

Schroeder B, Murphy S (1999) Population surveys (ground and aerial) on nesting beaches. In: Eckert KL, Bjorndal KA, Abreu-Grobois FA, Donnelly M (eds) Research and management techniques for conservation of sea turtles. Publ No. 4, IUCN Marine Turtle Specialist Group, Washington DC, p $45-55$

Editorial responsibility: Brendan Godley (Editor-in-Chief), University of Exeter, Cornwall Campus, UK
Seminoff JA (2004) 2004 IUCN Red List global status assessment: green turtle (Chelonia mydas). IUCN Marine Turtle Specialist Group Review, Gland

Solow AR, Bjorndal KA, Bolten AB (2002) Annual variation in nesting numbers of marine turtles: the effect of sea surface temperature on re-migration intervals. Ecol Lett 5: $742-746$

Taquet C, Taquet M, Dempster T, Soria M, Ciccione S, Roos D, Dagorn L (2006) Foraging of the green sea turtle Chelonia mydas on seagrass beds at Mayotte Island (Indian Ocean), determined by acoustic transmitters. Mar Ecol Prog Ser 306:295-302

Troëng S, Chaloupka M (2007) Variation in adult annual survival probability and remigration intervals of sea turtles. Mar Biol 151:1721-1730

Troëng S, Rankin E (2005) Long-term conservation efforts contribute to positive green turtle Chelonia mydas nesting trend at Tortuguero, Costa Rica. Biol Conserv 121: 111-116

Witzell WN (1994) The origin, evolution and demise of the US sea turtle fisheries. Mar Fish Rev 56:8-23

Submitted: June 25, 2007; Accepted: September 10, 2007 Proofs received from author(s): October 3, 2007 